\title{
ELABORATION OF THE REGIONAL CLUSTERS IN HOTEL ECONOMY
}

\author{
Svitlana Zhuravlova \\ Department of International Tourism \\ Zaporizhzhye National Technical University \\ 64 Zhukovs'kyi str., Zaporizhzhya, Ukraine, 69063 \\ s_n_zhuravlyova@mail.ru
}

\begin{abstract}
Absrtact
The modern approach to the cluster methodology usage in the sphere of hotel economy is presented in the article. It was proved, that the one of forms of such integration is a formation of hotel cluster. Just in the hotel cluster (association) and not at the level of separate hotel enterprise are formed such processes as: integration of objects, organization of unitary informational system; selective support by the local budget of building hotels and other lodging means; innovative policy and introduction of new technologies; allotment of the territory for building; revision of transport routes; development of engineer-technical nets and so on. There are presented the data about the situation and dynamics of development of the hotel services sector in Zaporizhzhya region. The analysis of hotel economy of Zaporizhzhya region testifies that the causes of significant fluctuations of the number of guests in hotels were not only the general economic crisis but also the appearance of new form of competition between autonomous hotels, hotel nets and private apartments of lodging type. The number of placed foreign citizens that are the source of currency costs and services export also changed. The results of analysis indicate the essential discrepancies between the main characteristics of the hotels of different, types, the comfort level and the state of material-technical base that is insufficiently developed.

The analysis of financial-economic activity of hotel complexes, especially, profitability of their work, testifies that the special attention of enterprise leaders must be paid to the reduction of spendings on exploitation of hotels that form the cost price of hotel services and, accordingly, their price. The features of inclusion of small hotels to the general strategy of hotel economy reorganization are determined.
\end{abstract}

Keywords: clusterization, hotel complexes, regions, process approach, innovations, enterprise of hotel economy, strategic management, hotel service, hotel cluster, integration.

\section{Introduction}

In the modern conditions of economy globalization the hotel business is under the influence of external and internal changes that compel the enterprises of hotel economy to search the new strategies, instruments and methods of the management, based on the systemic and complex approaches. For the development of hotel economy of Ukraine, the processes of combination and integration of hotel enterprises, formation of new modes and structures of the management become topical. In such connection the elaboration of principally new approaches to the development of regional hotel economy using new organizational forms and managerial methods become urgent.

\section{Analysis of recent studies}

The questions, connected with cluster analysis of hotel economy enterprises are considered in the work [1]. It presents the system of quality management as a totality of mutually dependent methods as to the satisfaction of requirements to the quality and reduction of costs on it. The segmentation of hotel economy market was considered in the work [2]. In the work [3] is described the methodology of strategic planning of clusters, based on the deepened understanding of the features of clusters as economic systems. The foreign and native scientists-economists also considered the role of clusters in creation of new type of business in the work [4]. The main example of creation of trade and productive clusters that have economic success in developed countries is presented in the work [5].

The special attention to the essence of market self-regulation and methods of state price regulation was paid in the work [6]. In the work [7] was considered the formation of organizationaleconomic principles of functioning of hotel economy as an important sector that can actively influence economy, economic, social and humanitarian base of the country. 


\section{Aim and tasks of research}

Aim of the article is in the study of formation of clusters relative to the objects of hotel economy taking into account the features of regional policy in this service sector and in separation of prototype of the future cluster.

The following tasks were formulated to achieve the set aim:

1. To consider the notion "clusterization of hotel economy".

2. To analyze the sector of hotel services in Zaporizhzhya region with further formation of cluster of the regional hotel complex.

3. To discover the cluster models that can be developed at the regional level.

\section{Materials and methods of research}

The research was based on the method of comparative and system analysis for the study of the system of hotel services and structural changes of hotel enterprises; method of correlativeregressive analysis was used for the study of dynamics of the volume of hotel services and their influence factors; economic-mathematical methods allowed to study the dynamics and tendencies of development of hotel economy enterprises, to assess and to elaborate the models of their further development. The informational base of research is: the publications of foreign and native scientists on the problems of hotel enterprise management; monographic economic literature; thematic publications in periodic issues; statistical materials and reports of State statistics of Ukraine; legislative and regulatory acts; the data of statistic reporting of separate hotel economy enterprises.

\section{Results of research}

The one of tested abroad and really effective forms of economic management of structural groups of objects is cluster methodology. In developed countries with market economy the clusters of regional type has been created during decades. The cluster kernel was the strong enterprises with qualified management and high level of corporative culture. The inclusion of non-uniformly scaled enterprises in the cluster favored the transfer of experience of management and corporative culture of basic enterprise - cluster kernel. The big enterprises in cluster conditions widen the horizon of their market possibilities and strengthen the existent potential. Small and middle ones strengthen their competitiveness and position at the markets. At the same time the one of tasks of cluster creation including small and middle enterprises in hotel economy is their adjustment of the continuous changes of competitive environment, market demand and investment climate.

The formation of real clusters in the region needs correspondent conditions, first of all, economic ones. There are conditions of strengthening of competitive dependence between the participants of hotel business, unitary infrastructure, need in the raise of service quality "class". The preparatory work for clusters creation needs not only the presence of "coercive objective factors" but also the coordinated work in the region for development of these conditions in the direction of positive changes [4].

The clusters including enterprises of small and middle business in the sphere of hotel economy can be created on the base of self-organization in the result of natural integration and cooperation of production or with the help of strategic planning, realized by the regional and municipal power. Enterprises - the potential participants of possible clusters - often produce the similar or attendant types of commodities (services) and are competitive relative to each other at the commodity markets and self-organization of entrepreneurs is realized in such case usually by initiative of entrepreneur-leader. In this connection the entrepreneurs' fear to lose the own business at inclusion in cluster is completely grounded and it gives the special role to the mechanism of coordination of conditions and interactions.

The high guarantees of observance of mutual duties are attained under condition of participation of the regional power bodies in this process. Administrations of the regions and municipal bodies make prognoses of clusters formation taking into account the spatial placement and specialization of hotel enterprises and organize the business contacts between entrepreneurs. Such organizational work also favors the strengthening of confidence between the probable participants of the cluster. 
The attainment of arrangements between entrepreneurs on formation of cluster assets and "rules of the game" is rather complicated moment at the initial stage of its creation. The combining factors of economic interests of cluster creation are the arrangements on unitary price policy at the commodity market, widening of the volumes of production of commodities and services by its participants, unitary marketing policy, common planning of introduction of innovative technologies, maintenance, supply and so on [4].

Clusterization of the hotel economy in the regions of the country and cities is closely connected with the process approach to the management. The transition to the process approach in management reflects the striving of concerned participants to integrate all types of activity as to the solution of managerial tasks into the unitary chain that was broken as the result of "excessive enthusiasm" for functional approach when the functional teams work beyond the connection between each other. At the process approach the attention is concentrated on interconnection of separate actions, each of them, in its turn, is a process. Thus, the management in cluster is presented as a dynamic process that changes in space and time but keeps logistical and net connection between cluster links that have intention to the common realization of accepted mission that is to solve the group tasks of enterprises in whole.

The managers, whose work is in organization and guidance of the efforts of the whole staff for attaining aims provide the conditions for effective and productive labor of workers of organization and obtaining final social and economic results. As far as management is also the ability to attain the set aims, using intellect and motives of human behavior, the attention to such factors as organizational culture (corporative culture), participation of workers in profit distribution, in making decisions, in choice and support of guidance style is strengthened in the cluster.

The use of clusterization methodology in the sphere of hotel services is widely used in Western countries, especially in the USA. For example in SAR is a practice of creation of tourist clusters at the national and local level and also the development of thematic tourist clusters (sport, adventure, cultural-cognitive, vine and other). Thus, the famous economist of XX century Alfred Marshall wrote in his works that the significant role in clusterization is played by the entrepreneurs' associations (for example, in Italy and series of European countries) [5].

The useful organizational-methodical support for the clusters formation is given by "Association of the small hotels and apartments of Ukraine" that unites near 50 enterprises. This public organization can be considered as the prototype of future cluster or rather protocluster. Its special role is in fact that relative to the status public organizations occupy the special place in the development of dialog between the business and power that is underlined by many famous theoreticians of cluster approach in economy. The complex of tasks of UPO "Association of the small hotels and apartments of Ukraine" is presented on the Fig. 1.

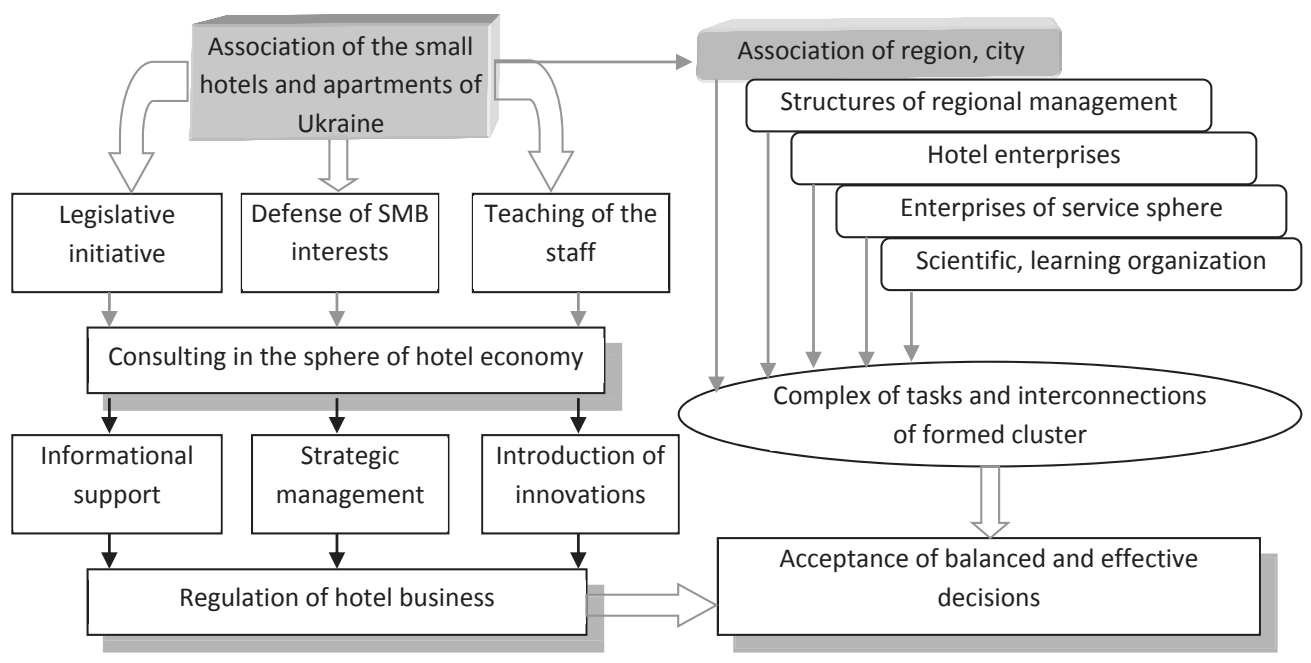

Fig. 1. The tasks of UPO "Association of small hotels and apartments of Ukraine" and its participation in clusters creation 
Thus the created UPO "Association of the small hotels and apartments of Ukraine", its activity and analysis of the structure allow separate the series of signs of combining-defending function of such associations, especially: striving for creation of the net form of organization by the horizontal and territory (geographic) signs; dialog with power structures; production of initiatives for the development of small hotels segment; striving for guaranteeing and support of competitive enterprises $[2,8]$.

As to the very order of formation of cluster of the regional hotel complex, the following logic can be accepted:

- inventorying of the main funds, assessment of productive structure, analysis of external environment;

- determination of economic and innovative potential of each potential cluster separately;

- marketing of the regional environment and benchmarking in the sphere of hotel services;

- organizational-legal and psychological preparation for integrative interconnections;

- determination of balance of positives and negatives, especially risks and benefits;

- elaboration of strategies of cluster development;

- coordination of norms and conditions of inclusion in cluster and activity in it;

- preparation for the conclusion of treaties.

In Zaporizhzhya region in the nearest future can be created the clusters of three types:

1. Groups of small hotels.

2. Leader and its net.

3. Special clusters (for example, including such enterprises as hostels, tourist bases, camping, dormitories and other).

At clusters creation the formed economic connections between hotel enterprises and suppliers must be taken into account. At the same time it is necessary to carry out the preparatory work that must include:

- creation of structural kernel for formation of cluster models;

- marketing work;

- elaboration of the policy and strategy in the field of the quality of offered services;

- elaboration of informational system and mechanisms of internal economic policy;

- determination of the order of working procedures of interaction between enterprises that demonstrated the desire to enter in the hotel cluster including internal standards.

Especially in Zaporizhzhya region the hotel service sector can be characterized in the following way.

The important parameter of development of hotel economy is a commissioning of new hotels in the region. There was also observed the change of structure of the property category of the hotel fund $[3,7]$.

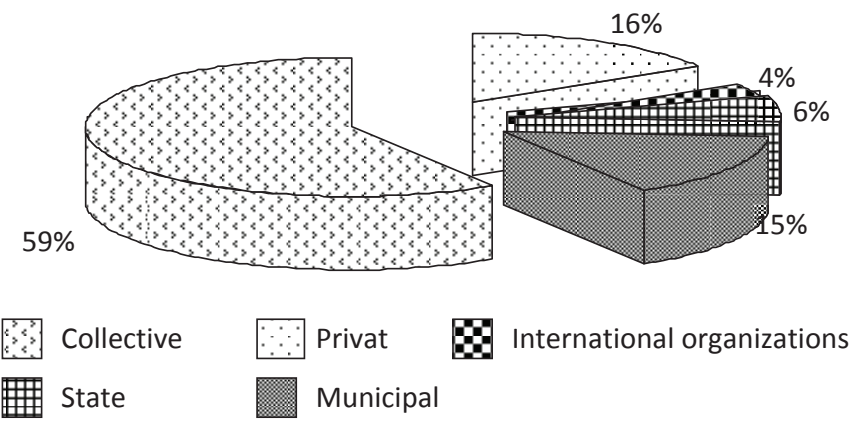

Fig. 2. The structure of property categories of hotel economy of Zaporizhzhya region in 2015

For today the most hotel enterprises of the region (59\%) have collective (joint-stock) property category, more than $16 \%$ are the private hotels, the other - municipal, state property and property of international organizations. The change of property categories was reflected also on the parameters of material-technique state of the regional hotel sector (Table 1). 
Table 1

The dynamics of main parameters of material-technique base of hotel economy in Zaporizhzhya region

\begin{tabular}{|c|c|c|c|c|c|}
\hline \multirow{2}{*}{ Parameters } & \multicolumn{3}{|c|}{ Years } & \multicolumn{2}{|c|}{ Changes, 2013/2011 } \\
\hline & 2013 & 2014 & 2015 & $(+/-)$ & $(\%)$ \\
\hline Number of hotels, units & 166 & 197 & 221 & 31 & 118,6 \\
\hline Disposable lodging capacity, places & 12883 & 13020 & 15234 & 137 & 101,0 \\
\hline Housing space of accommodation, thousand $\mathrm{m}^{2}$ & 106 & 108 & 113 & 2 & 101,8 \\
\hline Mean area of accommodation, $\mathrm{m}^{2}$ & 16,3 & 16,9 & 16,9 & 0,6 & 103,6 \\
\hline Mean lodging capacity of hotel enterprise, places & 78 & 83 & 89 & 5 & 106,4 \\
\hline Mean level of load, $\%$ & 20 & 19 & 20 & -1 & 95,0 \\
\hline Newly arrived that were placed, persons & 25316 & 29879 & 32534 & 4563 & 118,0 \\
\hline
\end{tabular}

The analysis testifies to the growth of the number of hotel enterprises in region (for the period 2013-2015 by 18,7\%) mainly at the expense of building new establishments with low lodging capacity and raised comfort and reconstruction of the series of existing hotels into the higher classes "luxe" and "semi-luxe" that also caused the lowering of general lodging capacity of establishments.

For the establishing the economic effectiveness of the activity of different types of hotels (net, autonomous and small hotels-private apartments) there was carried out an analysis of their financial condition and reporting according to the form 1-hotel, presented in the Table 2 that allows define the place of concrete hotel in economic environment and the effectiveness of business relation with business partners.

Table 2

The main economic parameters of the activity of studied hotel economy enterprises in Zaporizhzhya region

\begin{tabular}{|c|c|c|c|}
\hline Parameter & Autonomous hotels & Hotel nets & Small hotels \\
\hline Number of examined hotels, units & 7 & 4 & 8 \\
\hline Mean lodging capacity of hotel, places & 134 & 98 & 23 \\
\hline Mean area of accommodation, $\mathrm{m}^{2}$ & 18,3 & 16,7 & 15,4 \\
\hline Price of accommodation "standard", grn for a day & 430 & 580 & 280 \\
\hline Number of staff, persons for accommodation & 1,1 & 0,8 & 0,6 \\
\hline Loading coefficient, $\%$ & 25 & 47 & 36 \\
\hline Part of housing area, $\%$ & 43 & 51 & 54 \\
\hline Profit for accommodation, grn for a day & 176 & 337 & 96 \\
\hline Profit for worker, thousand grn & 169 & 421 & 466 \\
\hline Price for a day of staying, grn & 460 & 550 & 290 \\
\hline Especially of foreigners, grn & 1280 & 1380 & 380 \\
\hline Profit for unit of costs, grn & 32 & 64 & 43 \\
\hline Level of service quality (from 5 points) & 3,6 & 4,1 & 3,5 \\
\hline
\end{tabular}


The financial analysis demonstrated that the economic activity of net hotels is generally more effective comparing with autonomous ones [9].

The further widening and diversification of material base of hotel economy of the region will take place, from the one side, at the expense of elaboration of the net of high-class 4-star hotels in the main centers of tourist demand concentration, and from the other one, at the expense of development of small private hotels in rural area. It will allow raise the general level of the net of lodging accommodation of hotel type, widen and diversify the supply nomenclature and give Zaporizhzhya region the competitive positions among the main markets of hotel services of Central-Eastern Europe.

The processes of denationalization and further segmentation of the market of hotel services influenced the change of property category (mainly by corporatization way) and model of managerial structure of the hotels. The old material-technical base, insufficient financing of the state lodging accommodations, low competitiveness and high price cost of hotel services of cost-accounting enterprises led to the unprofitableness of most lodging establishments of the region, decrease of their number, reduction of the staff.

Thus for today the development of supply of lodging services in region takes place by the way of successive optimization of their quality-price criteria: creation of more comfortable conditions of staying, improvement of service quality at keeping relatively moderate prices and diversification of service assortment. On the base of world standards of quality there takes place also the transformation of organizational and technological principles of the activity of hotel economy enterprises $[1,6]$.

The main aims of the hotel complex development in region are:

- the supply of newly arrived persons with lodging services, high-quality rest, conditions for renewal of intellectual and emotional forces;

- stimulation of stable socioeconomic development of the region;

- raise of the effectiveness level of the hotel potential usage;

- raise of the hotel service quality.

Realization of these objective directives is intellectually and financially based, but they can help the hotel economy enterprises of the region to move to the new desired level of effectiveness and social usefulness.

The certain structure of the clusters of different type flows from the analysis of situation in the hotel economy of Zaporizhzhya region. We talk, first of all, about the different positions of participants of cluster organization for today. Such participants can be the associations with wide spectrum of connections in interregional space, hotel enterprises, already created in the world net structures, large regional hotel structures that must occupy the dominating positions in region by the volume of given services. The own cluster model can be created by the structures of small business that have the significant list of different small enterprises. It is expedient to form the cluster model of hotel economy enterprises gradually: to form the kernel of hotel cluster, regional and branch organizations combined with the hotel and other enterprises for giving additional and attendant lodging services.

The forms of organization and conditions of inclusion in cluster are unequal for the different forms of cluster organization [10].

\section{Discussion of results}

The advantage of the article is the analysis of: material-technical base and economic parameters of hotel enterprises and also the property categories of hotel economy of Zaporizhzhya region that allow form the mechanisms of development of hotel clusters, forms of organization of interaction and conditions of integration of enterprises.

At the same time, analyzing the organizational-economic conditions of cluster association of hotel economy enterprises it would be necessary to present the stages of hotel clusters formation in more details.

The studies of the article give managers a possibility to make the grounded managerial decisions as to the integration and formation of cluster model by the hotel economy enterprises and the raise of effectiveness of their activity at the hotel service market.

This article is a part of scientific work that was introduced in the hotel enterprise in the city Zaporizhzhya. 


\section{Conclusions}

Clusterization can be considered as the factor of stabilization and stable development of regional economy because its main result is not the formal reorganization but the effect of interaction synergy. The prototype of further cluster - "Association of the small hotels and apartments of Ukraine" - was separated.

It was revealed, that at the regional level it is expedient to create temporal or permanent structure that will be responsible for the work of analytic assessment of situation, strategic planning of integrating process, preparatory work. The cluster models in hotel complex must be formed gradually in three stages: kernel creation (I), inclusion of the blocs of informational support and cultural service (II), attraction of the small firms, health-improving centers, elements of bank service and so on to the influence zone (III).

The development of enterprise in the net hotel business and especially introduction of the new objects of net lodging means must be realized taking into account the prospects of their stable development on this territory, destination profile, prospective directions of tourism development, resource potential of the territory for avoiding degradation changes in anyone of three components of destination structure: political-economical, physical-ecological and socio-demographic.

\section{References:}

[1] Tkachenko, T. I. (2009). Stalyj rozvytok turyzmu: teoriya, metodologiya, realiyi biznesu: monografiya. Kyiv: Kyyivskyj nacionalnyj torgivelno-ekonshhmichnyj universytet, 463.

[2] Munin, G. B., Karyagin, Yu. O., Artemenko, A. S., Koshyl, Yu. V.; Trofymenko, L. S. Gacza, O. O. (Eds.) (2008). Franchajzyng u gotelno-restorannomu biznesi. Kyiv: Kondor, 370.

[3] Klejner, G. B., Kachalov, R. M., Nagrudnaja, N. B. (2007). Formirovanie strategii funkcionirovanija innovacionno-promyshlennyh klasterov. Moscow: CJeMI RAN, 120.

[4] Porter, M. (2003). Strategiya konkurenciyi. Kyiv: Osnovy, 496.

[5] Marshall, A. (2008). Osnovy ekonomicheskoj nauki. Moscow: Jeksmo, 832.

[6] Agafonova, L. G., Agafonova, O. E. (2002). Turizm, gotel'nij ta restorannij biznes: Cinoutvorennja, konkurencija, derzhavne reguljuvannja: navch. posib. Kyiv: Znannja Ukraini, 358.

[7] Bojko, M. G., Myhajlichenko, G. L. (2013). Klastery yak innovacijna forma ekonomichnogo rozvytku regioniv. Visnyk D1TB, 16, 16-25.

[8] Pro associaciju malyh gostinic i apartamentov Ukrainy (2014). Available at: http://www.smallhotels.com.ua

[9] Gostinicy i drugie mesta dlja vremennogo prozhivanija (2015). Available at: http:/www.ukrstat.gov.ua/

[10] Bojko, M. G. (2004). Formuvannya priorytetnyh napryamiv rozvytku pidpryyemstv gotelnogo gospodarstva. Visnyk Doneczkogo instytutu turystychnogo biznesu, 8, 202-211. 